\title{
The role of pesticides in the etiology of lymphoma: A systematic review
}

\section{Lenfoma etiyolojisinde pestisitlerin rolü: Sistematik derleme}

\author{
Derya Adibelli ${ }^{1 *}$ \\ ${ }^{1}$ Assist. Prof., Kumluca Health Science Faculty Department of Public Health Nursing, Akdeniz University, Antalya, Turkey \\ * Corresponding author: Derya Adibelli E-mail: aricanderya@gmail.com ORCID: 0000-0001-9320-7083 \\ Received: 30 October 2019 Accepted: 20 December 2019
}

\begin{abstract}
Aim: It is known that non-Hodgkin lymphoma risk increases in agricultural workers and it is thought that pesticides have an effect on this increase. The aim of this systematic review is to evaluate the role and effect of pesticides in the etiology of lymphoma.
\end{abstract}

Material and Methods: This systematic review was conducted in accordance with the Centre for Reviews and Dissemination 2009 guide developed by York University National Institute of Health Research. It was carried out in the databases Science Direct, EBSCO (CINAHL Complete), PUBMED, Wiley Interscience, Springer Link databases to cover the years 2014-2019.

Results: As a result of the review, six studies were included in the research and presented in "year of study, research type and sample characteristics, measurement tools used, results obtained, and level of evidence".

Conclusion: It was found that pesticide use was associated with the risk of non-Hodgkin lymphoma and its subtypes. Occupational exposures should be assessed in communities whose main livelihood is agriculture and this group should be trained by health professionals on the use of personal protective equipment and protective behaviors.

Keywords: lymphoma, non-Hodgkin lymphoma (NHL), pesticide, systematic review 


\section{ÖZ}

Amaç: Tarım çalışanlarında non-Hodgkin lenfoma riskinin arttığı bilinmektedir ve bu artışta pestisitlerin rolü olduğu düşünülmektedir. Bu sistematik derlemenin amacı lenfoma etiyolojisinde pestisitlerin rolünü ve etkisini değerlendirmektir.

Gereç ve Yöntemler: Bu sistematik derleme York Üniversitesi Ulusal Sağlık Araştırmaları Enstitüsü tarafından geliştirilen Derleme ve Yaygınlaştırma Merkezi 2009 kılavuzuna uygun olarak yürütülmüştür. Çalışmaya ilişkin taramalar 2014-2019 yıllarını kapsayacak şekilde Science Direct, EBSCO (CINAHL Complete), PUBMED, Wiley Interscience ve Springer Link veri tabanlarında yapılmıştır.

Bulgular: Tarama sonucunda, kriterlere uyan altı çalışma araştırma kapsamında alınmıştır. Sonuçlar "Çalışmanın yılı, araştırma tipi ve örneklem özellikleri, kullanılan ölçüm araçları, elde edilen sonuçlar ve kanıt düzeyi" başlıkları altında tablo olarak sunulmuştur.

Sonuç: Pestisit kullanımının non-Hodgkin lenfoma ve alt tipleri ile ilişkili olduğu bulunmuştur. Tarımın ana geçim kaynağı olduğu toplumlarda mesleki maruziyet değerlendirilmeli ve bu grup kişisel koruyucu ekipman kullanımı ve koruyucu davranışlar konularında sağlık profesyonelleri tarafından eğitilmelidir.

Anahtar kelimeler: lenfoma, non-Hodgkin lenfoma (NHL), pestisit, sistematik derleme

\section{INTRODUCTION}

Pesticides are commonly used with the purpose of preventing the loss of yield in food sources to meet the needs of the growing world population, and these products have serious negative impacts on human health. The length of stay in nature of pesticides may vary between 3-17 years. Pesticides entering the body through digestion, respiration or skin can easily cross the white blood cell and red blood cell membrane by binding to serum lipoproteins through blood circulation and may damage the health by accumulating in different tissues and organs of the body such as liver, brain, adrenal glands, muscle tissue and especially fatty tissue [1].

It is known that the risk of Non-Hodgkin's Lymphoma (NHL) increases in agricultural workers [2-5]. Different exposures may contribute to this increased risk, and pesticides are considered to have a significant role [6]. Despite the widespread use of pesticides, there are a limited number of studies examining the relationship between the risk of $\mathrm{NHL}$ and pesticides in the general population. The International Agency for Research on Cancer study group classified organochlorine pesticides as NHL-associated carcinogens $[7,8]$. The same study group reported that there was a positive relationship between dichloro diphenyl trichloroethane (DDT) and liver, testis, and NHL [8]. In another study, it was found that high DDT level increased the risk of $\mathrm{NHL}$ [9]. Although most studies reported increased NHL risk with organochlorine exposure [10-12], there are also studies indicating that there is no relationship [13-15].

Organophosphate and carbamate group pesticides have serious negative effects on human health such as cancer $[16,17]$. The International Agency for Research on Cancer classified organophosphates as possible human carcinogens [18]. In large prospective cohort studies, it was reported that there was a positive relationship between the use of organophosphate group pesticides and NHL [19,20]. The aim of this systematic review was to investigate the role of pesticides in the etiology of lymphoma. This systematic review was initiated with the question "Do pesticides have effects on the formation of lymphoma?"

\section{MATERIAL AND METHODS}

This study is a systematic review carried out to investigate the role of pesticides in the etiology of lymphoma. The review was carried out in accordance with the Center for Reviews and Dissemination (CRD) 2009 guide developed by the York University National Institute for Health Research. The literature review was conducted in the "Science Direct, EBSCO (CINAHL Complete), PUBMED, Springer Link, Wiley Interscience" databases covering the years between 2014 and 2019. The review was carried out between April and August 2019. The key words "Lymphoma" "Pesticide", "Lymphoma and pesticide" were used in the review. While the inclusion criteria of this systematic review were casecontrol and cohort studies carried out in those who used or were exposed to pesticides regardless of age group and gender, the exclusion criteria were determined as the 


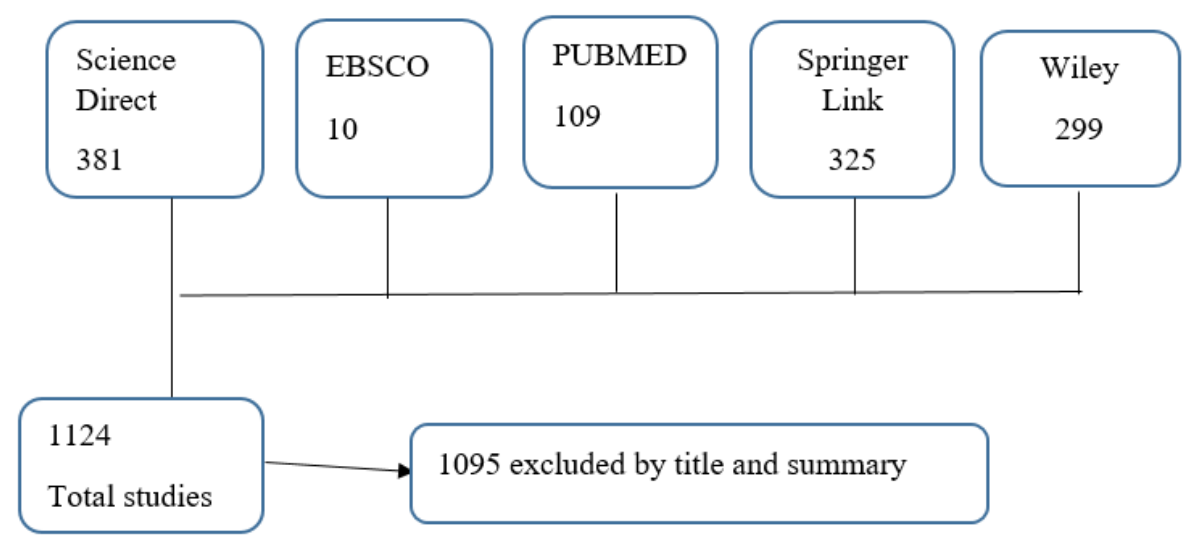

29 those the full texts of which were evaluated

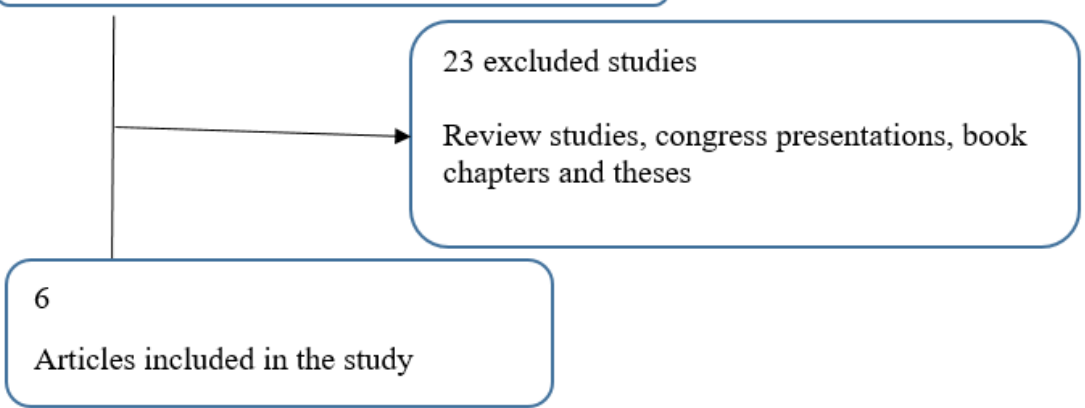

Figure 1. Preferred Reporting Items for Systematic Reviews and Meta-Analyses (PRISMA) Flow Chart

reviews, congress reports, theses, and book chapters. As a result of the review, a total of 1124 (Science Direct: 381, EBSCO (CINAHL Complete): 10, PUBMED: 109, Springer Link: 325, Wiley Interscience: 299) studies were reached. At the end of the eliminations made in accordance with the criteria, six studies were included in the study (Figure 1).

The level of evidence of each study was evaluated according to the Melnyk and Fineout-Overholt classification: Systematic review or meta-analysis (Level I), Randomized controlled trial (Level II), Controlled trial without randomization (Level III), Case-control or cohort study (Level IV), Systematic review of qualitative or descriptive studies (Level V), Qualitative or descriptive study (Level VI), Expert opinion or consensus (Level VII) [21]. This review followed the recommendations proposed by Preferred Reporting Items for Systematic Reviews and Meta-analyses [22].

\section{RESULTS}

As a result of the review, six studies that met the inclusion criteria were included in the systematic review (Figure). The results obtained from the studies are presented by being grouped under the headings of "Study/Year, Research Type/Sample Characteristics, Measurement Tools Used, Results Obtained, and Level of Evidence" (Table 1).

\section{Sample Characteristics}

The studies under review were cohort and case-control studies and all of them were observational studies. When sample characteristics were examined, the cases diagnosed with lymphoma and one of its subtypes on a yearly basis regardless of age group and gender were reviewed. The participants in the case-control group were usually selected from the existing hospital/health records or from the results of prospective cohort studies. It was determined that the minimum and maximum numbers of samples were 158 [23] and 1690 [24], respectively.

\section{Measurement Tools Used}

Different measurement tools and methods were used in the studies included in the review. Cancer records [19], SEER coding scheme for the classification of NHL and its subtypes [19], WHO Lymphoma Classification [23], International Classification of Oncology [24], InterLymph Consortium Classification [6], socio-demographic information questionnaire form $[19,23,24]$, questionnaire form examining the use of pesticides $[6,19,24]$, CAREX database [23] were used. Gas chromatograph and chemistry analyzer were used to perform laboratory analyses in two studies $[25,26]$. 
Table 1. Scientific Researches on the Relationship between Lymphoma and Pesticide*

\begin{tabular}{|c|c|c|c|c|}
\hline $\begin{array}{l}\text { Study/Yea } \\
\text { rs }\end{array}$ & $\begin{array}{l}\text { Research Type / Sample } \\
\text { Characteristics }\end{array}$ & Measurement Tools Used & Results Obtained & $\begin{array}{l}\text { Level of } \\
\text { Evidence }\end{array}$ \\
\hline $\begin{array}{l}\text { Alavanja et } \\
\text { al., } 2014\end{array}$ & $\begin{array}{l}\text { Prospective cohort study. } \\
523 \mathrm{NHL} \text { cases. }\end{array}$ & $\begin{array}{l}\text { - State Cancer Records } \\
\text { - SEER coding scheme in the classification of NHL } \\
\text { and its subtypes (based on Pathology Working } \\
\text { Group of the International Lymphoma } \\
\text { Epidemiology Consortium) } \\
\text {-Socio-demographic information questionnaire } \\
\text { - Algorithm questioning whether to mix } \\
\text { pesticides, method of application, repair of } \\
\text { equipment or use of personal protective } \\
\text { equipment }\end{array}$ & $\begin{array}{l}\text { It was found that the use of herbicides had a small but significant effect } \\
\text { on the risk of some NHL subtypes, however, it did not affect the risk of } \\
\mathrm{NHL} \text { in general. } \\
\text { Lindane was the only pesticide with a statistically significant increase for } \\
\text { the risk of NHL with both exposure measurements. } \\
\text { DDT indicated that there was a significant trend for the risk of NHL on } \\
\text { the days of lifetime use. } \\
\text { For follicular lymphoma, lindane showed a non-significant relationship. } \\
\text { Lifelong use of lindane was found to be associated with the risk of NHL. }\end{array}$ & IV \\
\hline $\begin{array}{l}\text { Bassig et } \\
\text { al., } 2019\end{array}$ & $\begin{array}{l}\text { Case-control study. Case } \\
\text { and control groups were } \\
\text { identified from the } \\
\text { results of three } \\
\text { prospective cohort } \\
\text { studies. } 167 \mathrm{NHL} \text { cases. }\end{array}$ & $\begin{array}{l}\text { - Gilson } 215 \text { liquid handler } \\
\text { - Chromatography isotope dilution high } \\
\text { resolution mass spectrometer } \\
-912 \text { Chemistry Analyzer (Hitachi, Tokyo, Japan) }\end{array}$ & $\begin{array}{l}\text { It was determined that } \mathrm{pO}-\mathrm{DDE} \text {, one of } \mathrm{OC} \text { pesticides, had the highest } \\
\text { concentration in both } \mathrm{NHL} \text { cases and controls. } \mathrm{V}-\mathrm{HCH} \text { and pODDE } \\
\text { concentrations in cases and controls showed great differences between } \\
\text { individual cohorts. They were observed at very high levels in Shanghai } \\
\text { compared to Singapore. } \\
\text { A strong relationship was found between B-HCH levels and general } \\
\mathrm{NHL} \text {. } \\
\text { No significant exposure-response relationship was observed between } \\
\text { other OC pesticide levels and the risk of NHL. HCB concentrations were } \\
\text { not associated with overall risk of NHL, except for lymphoid leukemia. } \\
\text { However, high HCB levels were found to be associated with NHL among } \\
\text { the cases diagnosed in both groups } 7 \text { years after blood collection. }\end{array}$ & IV \\
\hline $\begin{array}{l}\text { Ferri et al., } \\
2017\end{array}$ & $\begin{array}{l}\text { Retrospective case- } \\
\text { control study. } 158 \\
\text { lymphoma cases } \\
\text { including } 30 \mathrm{HL} \text { cases } \\
\text { and } 128 \mathrm{NHL} \text { cases that } \\
\text { were first diagnosed } \\
\text { during the study period. }\end{array}$ & $\begin{array}{l}\text {-World Health Organization (WHO) lymphoma } \\
\text { classification (2008) } \\
\text { - } 40 \text { ml blood sample for biological exposure } \\
\text { parameters (serum polychlorinated biphenyls } \\
\text { [PCB], aryl hydrocarbon receptors [AHR], } \\
\text { lymphocytic oxidative) } \\
\text {-Socio-demographic information questionnaire } \\
\text {-CAREX database to evaluate occupational } \\
\text { exposure to pesticides }\end{array}$ & $\begin{array}{l}\text { No statistical significance was found between the risk of lymphoma and } \\
22 \text { chemical products. } \\
\text { Increased risk was detected for all lymphomas in cases exposed to } \\
\text { Captafol, exposed to Low Paraquat levels and Moderate radon levels. }\end{array}$ & IV \\
\hline $\begin{array}{l}\text { Koutros et } \\
\text { al., } 2019\end{array}$ & $\begin{array}{l}\text { Case-control study. } 1690 \\
\text { NHL cases }\end{array}$ & $\begin{array}{l}\text {-International Classification of Diseases for } \\
\text { Oncology First Edition (ICDeOe1) to classify NHL } \\
\text {-Socio-demographic information questionnaire } \\
\text { - Questionnaire form for pesticide use }\end{array}$ & $\begin{array}{l}\text { Significantly increased risk of NHL was found among malathion users. A } \\
\text { statistically significant relationship was found between the duration of } \\
\text { pesticide use and the risk of NHL. A weighted normalized (Z-score) one- } \\
\text { unit change between pesticides increases the risk of NHL by } 38 \% \text {. } \\
\text { A positive relationship was found between the use of OP and } \\
\text { carbamate insecticides and the subtypes of lymphoma. } \\
\text { Furthermore, a significant increased risk was also found in the use of } \\
\text { carbonfuran and DLBCL. }\end{array}$ & IV \\
\hline $\begin{array}{l}\text { Klil-Drori } \\
\text { et al., } 2018\end{array}$ & $\begin{array}{l}\text { Hospital-based case- } \\
\text { control study. } 90 \text { cases, } \\
120 \text { control. }\end{array}$ & - Gas chromatograph & $\begin{array}{l}\text { It was found that DDE and HCB levels were not associated with B-NHL. } \\
\text { However, } \mathrm{PCB} \text { was found to be associated with B-NHL. }\end{array}$ & IV \\
\hline $\begin{array}{l}\text { Schinasi et } \\
\text { al., } 2015\end{array}$ & $\begin{array}{l}\text { Prospective cohort study. } \\
822 \mathrm{NHL} \text { cases. }\end{array}$ & $\begin{array}{l}\text {-InterLymph Consortium classification } \\
\text {-World Health Organization Lymphoma } \\
\text { classification } \\
\text { - Questionnaire form for pesticide use }\end{array}$ & $\begin{array}{l}\text { It was found that the risk of NHL was } 24 \% \text { higher in those who reported } \\
\text { pesticide application. } \\
\text { It was found that the risk of DLBCL was } 49 \% \text { in those who used } \\
\text { pesticides by mixing and } 72 \% \text { in those who used pesticides intensively. } \\
\text { This risk was high in young women. } \\
\text { Women who use pesticides for domestic animals had } 71 \% \text { higher risk of } \\
\text { plasma cell neoplasms. } \\
\text { It was determined that the use of powder or spray in domestic animals } \\
\text { increased the risk of follicular lymphoma by } 62 \% \text {. }\end{array}$ & IV \\
\hline
\end{tabular}

In the study of Alavanja et al., information on tumor characteristics was obtained from state cancer records. The classification of $\mathrm{NHL}$ and its subtypes was examined according to the SEER coding scheme based on Pathology Working Group of the International Lymphoma Epidemiology Consortium classification. 1. Small B-cell lymphocytic lymphomas (SLL), chronic B-cell lymphocytic lymphomas (CLL), mantle-cell lymphomas ( $M C L)$; 2. Diffuse large B cell lymphomas; 3. Follicular lymphomas; 4. 'Other Bcell lymphomas' consisting of a diverse set of B-cell lymphomas; 5. Multiple myeloma; and 6. T-cell NHL and undefined cell type. First information on the use of 50 pesticide species was obtained from the questionnaire form that was filled out during cohort record. Three cumulative exposure measures were used to determine pesticide exposure: (i) lifetime days of pesticide use (namely, years of use of a particular pesticide and number of days used per year); (ii) usage intensity-based lifetime days (namely, product of exposure days and exposure intensity measure) and (iii) using each pesticide. Information on usage density 
was derived from an exposure algorithm based on individual declaration (for instance, whether they mix pesticides, method of application, whether to repair equipment, or whether they use personal protective equipment) [19].

In the study of Bassig et al., samples conforming to standards were obtained using Gilson 215 liquid handler (Gilson Inc., Middleton, WI), and they were extracted by automated liquid-liquid extraction (LLE) using a liquid handler. The measurement of target analyses was performed using a chromatography isotope dilution high resolution mass spectrometer (GC-IDHRMS). Case-control pairs were analyzed sequentially in the sequential batch and laboratory workers were blinded according to the control status of the samples [25].

In the study of Ferri et al., 158 lymphoma cases that were first diagnosed during the study period were included, and each case was reviewed and classified using the World Health Organization (WHO) lymphoma classification. The control group was selected based on the same gender, same age class and the same the province of residence. Sociodemographic information was collected with a questionnaire form. CAREX database was used to evaluate occupational exposure to known and suspected carcinogenic pesticides [23].

In the study of Koutros et al., International Classification of Oncology (ICDeOe1) was used in the classification of NHL and its subtypes: follicular lymphoma (FL), di large B-cell lymphoma (DLBCL), small lymphocytic lymphoma (SLL) and "other". "Other" subtype histologies include all cases of FL or DLBCL or non-SLL or unknown. The cases and controls were matched by settlement (state/province) and age ( \pm 2 or 5 years). Other variables related to $\mathrm{NHL}$ risk factors such as demographic data, agricultural exposures (including use of pesticides) and lifestyle, medical and occupational history were obtained from the participants through questionnaire form [24].

In the study of Klil-Drori et al., serum blood samples were studied. The measurements of six organochlorine pesticides (DDT, DDE, b-hexachlorocyclohexane [b-HCH], a-HCH, hexachlorobenzene $[\mathrm{HCB}]$ and $\mathrm{g}-\mathrm{HCH}$ [lindane]) were performed using gas chromatography combined with an electron capture detector [26].

In the study of Schinasi et al., Hodgkin Lymphoma (HL) neoplasms were categorized according to InterLymph Consortium recommendations and World Health Organization subtypes. The questionnaire form examining the use of pesticides at home or at work, form of use, mixing conditions of pesticides was used [6].

\section{Results Obtained}

In the study of Alavanja et al., NHL cases were detected in 523 cases, including 148 SLL / CLL / MCL, 117 diffuse large $B$ cell lymphoma, 67 follicular lymphoma, 53 other B cell lymphoma (consisting of various $B$ cell lymphoma sets) and 97 MM cases. It was found that the use of herbicides had a small but significant effect on the risk of some NHL subtypes, however, it did not affect the risk of NHL in general. Lindane was the only pesticide with a statistically significant increase for the risk of NHL. DDT indicated that there was a significant trend for the risk of NHL on the days of lifetime use. The relationship between the risk of follicular lymphoma and lindane was not statistically significant. Lifelong use of lindane was found to be associated with the risk of NHL [19].

In the study of Bassig et al., it was determined that p0-DDE, one of organochlorine (OC) pesticides, had the highest concentration in both $\mathrm{NHL}$ cases and controls. $\mathrm{V}-\mathrm{HCH}$ and pODDE concentrations in cases and controls showed great differences between individual cohorts. A strong relationship was found between $\mathrm{B}-\mathrm{HCH}$ levels and general $\mathrm{NHL}$. No significant exposure-response relationship was observed between other $\mathrm{OC}$ pesticide levels and the risk of $\mathrm{NHL}$. HCB concentrations were not associated with overall risk of $\mathrm{NHL}$, except for lymphoid leukemia. However, high $\mathrm{HCB}$ levels were found to be associated with $\mathrm{NHL}$ among the cases diagnosed in both groups 7 years after blood collection [25].

In the study of Ferri et al., no statistical significance was found between the risk of lymphoma and 22 chemical products. Increased risk was detected for all lymphomas in cases exposed to captafol, exposed to low paraquat levels and moderate radon levels [23].

In the study of Koutros et al., significantly increased risk of $\mathrm{NHL}$ was found among malathion users. A statistically significant relationship was found between the duration of pesticide use and the risk of NHL. A weighted normalized (Zscore) one-unit change between pesticides increases the risk of $\mathrm{NHL}$ by $38 \%$. A positive relationship was found between the use of organophosphate (OP) and carbamate insecticides and the subtypes of lymphoma. Furthermore, a significant increased risk was also found in the use of carbonfuran and DLBCL [24].

In the study of Klil-Drori et al., it was found that DDE and HCB levels were not associated with $\mathrm{B}-\mathrm{NHL}$ and that $\mathrm{PCB}$ increased the risk of B-NHL [26]. 
In the study of Schinasi et al., it was found that the risk of NHL was $24 \%$ higher in those who reported pesticide application. It was found that the risk of DLBCL was $49 \%$ in those who used pesticides by mixing and $72 \%$ in those who used pesticides intensively. This risk was high in young women. Women who use pesticides for domestic animals had $71 \%$ higher risk of plasma cell neoplasms. It was determined that the use of powder or spray in domestic animals increased the risk of follicular lymphoma by $62 \%$ [6].

\section{DISCUSSION}

DDT is one of the organochlorine pesticides that achieved success in the control of malaria and typhus during and after World War II [27]. It was used actively in pest control in the United States of America (USA) from the mid-1940s to the 1960s [28]. Although this product was banned for agricultural use around the world in 2009, it is still used in vector control in some countries [29]. Permethrin is one of the broad-spectrum synthetic pyrethroid pesticides commonly used in home and horticulture. Since it was found to be associated with liver tumors in animal experiments, it was classified as possible human carcinogen by The U.S. Environmental Protection Agency (EPA) [30]. Although terbufos, which is an organophosphate insecticide, was classified in the "non-carcinogenic group" by EPA [31], it was determined in the study of Alavanja et al. that the use of terbufos was associated with the risk of NHL and some subtypes [19]. Malathion was classified as "possible human carcinogen" by International Agency for Research on Cancer (IARC). While case-control studies carried out in different sample groups [32-34] indicated that there was a positive relationship between the use of malathion and the risk of $\mathrm{NHL}$, as in the study of Koutros et al. [24] it was concluded in the study of Alavanja et al. that it was not associated [19]. These differences between the results may be due to time differences between exposure and disease development, differences in the use of pesticides, differences in sample groups examined, or differences in study types.

The carcinogenic mechanism of captafol is linked to interaction with thiol groups and cysteine that reduce defense against oxidative agents, lead to the formation of metabolites such as tetrahydrophthalimide, and lead to the formation of NS bonds with other biological substrates [35]. Moreover, it was reported that the risk of NHL was increased in the users of paraquat which is a herbicide commonly used in agriculture [36]. Acute exposure to paraquat may lead to fatal poisoning, and chronic exposure may pave the way for respiratory diseases and Parkinson's disease [37]. In the study of Ferri et al., the result that exposure to captafol and paraquat was associated with the risk of lymphoma supports the literature on carcinogenic mechanism [23].

In the literature, it was found that Lindane [27,34,38], DDT [9,19,39-41], terbufos [19], diazinon [33] and numerous organochlorine pesticides $[42,43]$ were associated with the increased risk of NHL and its subtypes. It was reported that the use of pesticides induced oxidative stress by causing destruction in cell proliferation [44], triggered inflammatory response [45] and had an effect on genotoxicity. In some studies, it was indicated that pesticide exposure was associated with common chromosomal changes $[46,47]$ Accordingly, it will be highly valuable to investigate potential biological mechanisms that directly affect the relationship between pesticide exposure and lymphoma.

Most epidemiological studies reflect the data of sample groups with male employees evaluating occupational exposure rather than household exposure. In a case-control study carried out with women working on the farm for 10 years or more, it was found that the NHL risk of women working on the farm was 2.12 times higher compared to those who did not work on the farm [48]. The risk of acute myeloid leukemia was also found to be higher in women living on the farm compared to women living in the city [49]. In the study of Schinasi et al., high risk of $\mathrm{NHL}$ and its subtypes among women living in farms supports the literature [6].

\section{CONCLUSION}

In six studies included in the review, it was demonstrated that pesticide use was associated with the risk of NHL and its subtypes. Although large-scale prospective cohort studies add important information at the level of evidence to the literature on this risk relationship, additional studies are needed on suspected professional factors. In addition to healthy lifestyle behaviors in the prevention of cancer, occupational applications and exposures should be evaluated if there are occupational cancers, and preventive health behaviors should be applied. At this point, workers should be informed about the use of personal protective equipment in agriculture. Healthcare professionals working with communities the main source of income is agriculture have significant roles in educating and informing the people.

\section{DECLARATION OF CONFLICT OF INTEREST}

The authors received no financial support for the research and/or authorship of this article. There is no conflict of interest. 


\section{REFERENCES}

1. https://acikders.ankara.edu.tr/pluginfile.php/62780/mo d_resource/content/0/4.pdf (Accessed September 26, 2019).

2. Blair A, Dosemeci M, Heineman EF. Cancer and other causes of death among male and female farmers from twenty-three states. Am J Ind Med 1993; 23(5): 729-42.

3. Blair A, Zahm SH. Agricultural exposures and cancer. Environ Health Perspect 1995; 103(8 Suppl): 205-8.

4. Keller-Byrne JE, Khuder SA, Schaub EA, McAfee O. Ametaanalysis of non-Hodgkin's lymphoma among farmers in the central United States. Am J Ind Med 1997; 31(4): 4424.

5. Khuder SA, Schaub EA, Keller-Byrne JE. Meta-analyses of non-Hodgkin's lymphoma and farming. Scand J Work Environ Health 1998; 24(2): 255-61.

6. Schinasi LH, De Roos AJ, Ray RM, et al. insecticide exposure and farm history in relation to risk of lymphomas and leukemias in the Women's Health Initiative observational study cohort. Annals of Epidemiology 2015; 25: 803-10.

7. Guyton KZ, Loomis D, Grosse Y, et al. Carcinogenicity of pentachlorophenol and some related compounds. Lancet Oncol 2016; 17: 1637-8.

8. Loomis D, Guyton K, Grosse Y, et al. Carcinogenicity of lindane, DDT, and 2,4-dichlorophenoxyacetic acid. Lancet Oncol 2015; 16: 891-2.

9. Engel LS, Laden F, Andersen A, et al. Polychlorinated biphenyl levels in peripheral blood and non-Hodgkin's lymphoma: a report from three cohorts. Cancer Res 2007; 67: 5545-52.

10. De Roos AJ, Hartge $P$, Lubin JH, et al. Persistent organochlorine chemicals in plasma and risk of nonHodgkin's lymphoma. Cancer Res 2005; 65: 11214-26.

11. Colt JS, Rothman N, Severson RK, et al. Organochlorine exposure, immune gene variation, and risk of nonHodgkin lymphoma. Blood 2009; 113: 1899-905.

12. Freeman MD, Kohles SS. Plasma levels of polychlorinated biphenyls, non-Hodgl,n lymphoma, and causation. J Environ Public Health 2012: 258981.
13. Laden F, Bertrand KA, Altshol L, Aster JC, Korrick SA, Sagiy SK. Plasma organochlorine levels and risk of nonHodgkin lymphoma in the Nurses' Health Study. Cancer Epidemiol Biomark Prev 2010; 19: 1381-4.

14. Cocco P, Brennan P, Ibba A, et al. Plasma polychlorobiphenyl and organochlorine pesticide level and risk of major lymphoma subtypes. Occup Environ Med 2008; 65: 132-40.

15. Zani C, Ceretti E, Covolo L, Donato F. Do polychlorinated biphenyl cause cancer? A systematic review and metaanalysis of epidemiological studies on risk of cutaneous melanoma and non-Hodgkin lymphoma. Chemosphere 2017; 183: 97-106.

16. Blair A, Ritz B, Wesseling C, Freeman LB. Pesticides and human health. Occup Environ Med 2015; 72: 81-2.

17. Koutros S, Beane Freeman LE, Lubin JH, et al. Risk of total and aggressive prostate cancer and pesticide use in the Agricultural Health Study. Am J Epidemiol 2013; 177: 5974.

18. International Agency for Research on Cancer (IARC). Malathion. 112 IARC, Lyon, France. 2015. https://www.iarc.fr/wp-content/uploads/2018/07/Mono graphVolume112-1.pdf (Accessed September 27, 2019).

19. Alavanja MC, Hofmann JN, Lynch CF, et al. Non-hodgkin lymphoma risk and insecticide, fungicide and fumigant use in the agricultural health study. PLoS One 2014; 9: e109332.

20. Bonner MR, Williams BA, Rusiecki JA, et al. Occupational exposure to terbufos and the incidence of cancer in the Agricultural Health Study. Cancer Causes Control 2010; 21:871-7.

21. Fineout-Overholt E, Melnyk BM, Stillwell SB, Williamson KM. Evidence-based practice step by step: critical appraisal of the evidence: part I. Am J Nurs 2010; 110(7): 47-52.

22. Moher D, Liberati A, Tetzlaff J, et al. Preferred reporting items for systematic reviews and meta-analyses: the PRISMA statement. Ann Intern Med 2009; 151(4): 264-9.

23. Ferri MA, Specchia G, Mazza P, et al. risk of lymphoma subtypes by occupational exposure in Southern Italy. J Occup Med Toxicol 2017; 12(31): 1-10. 
24. Koutros S, Harris SA, Spinelli JJ, et al. Non-Hodgkin lymphoma risk and organophosphate and carbamate insecticide use in the North American pooled project. Environ Int 2019; 127: 199-205.

25. Bassig BA, Shu XO, Sjödin A, et al. Prediagnostic blood levels of organochlorines and risk of non-Hodgkin lymphoma in three prospective cohorts in China and Singapore. Int J Cancer 2019: 1-11.

26. Klil-Drori AJ, Kleinstern G, Seir RA, et al. Serum organochlorines and non-Hodgkin lymphoma: a case control study in Israeli Jews and Palestinians. Chemosphere 2018; 213: 395-402.

27. Purdue MP, Hoppin JA, Blair A, Dosemeci M, Alavanja MCR. Occupational exposure to organochlorine insecticides and cancer incidence in the Agricultural Health Study. Int J Cancer 2007; 120(3): 642-9.

28. Environmental Protection Agency (EPA). DDT-A Brief History and Status. 2012. http://www.epa.gov/pestici des/factsheets/chemicals/ddt-brief-history-status.htm

(Accessed October 1, 2019).

29. Stockholm Convention Report. Report of the conference of the Parties of the Stockholm Convention on Persistent Organic Pollutants on the work of its 4th meeting. Fourth Meeting, Geneva, 2009. http://chm.pops.int/Portals/0/ Repository/COP4/UNEP-POPS-COP.4-38.English.pdf (Accessed September 25, 2019).

30. National Pesticide Information Center (NPIC). Chemicals Evaluated for Carcinogenic Potential, Office of Pesticide Programs. U.S. Environmental Protection Agency. 2012. http://npic.orst.edu/chemicals_evaluated.pdf (Accessed September 29, 2019).

31. Environmental Protection Agency (EPA). Re-registration Eligibility Decision for Terbufos. 2006. http://www.epa. gov/pesticides/reregistration/REDs/terbufos_red.pdf (Accessed October 2, 2019).

32. Cantor KP, Blair A, Everett G, et al. Pesticides and other agricultural risk factors for non-Hodgkin's lymphoma among men in lowa and Minnesota. Cancer Res 1992; 52: 2447-55.

33. Waddell BL, Zahm SH, Baris D, et al. Agricultural use of organophosphate pesticides and the risk of nonHodgkin's lymphoma among male farmers (United States). Cancer Causes Control 2001; 12: 509-17.
34. McDuffie HH, Pahwa P, McLaughlin JR, et al. NonHodgkin's lymphoma and specific pesticide exposures in men: cross-Canada study of pesticides and health. Cancer Epidemiol Biomark Prev 2001; 10: 1155-63.

35. National Toxicological Program. Captafol. Rep Carcinog 2011; 12: 83-6.

36. Park SK, Kang D, Beane-Freeman L, et al. Cancer incidence among Paraquat exposed pesticide applicators in the agricultural health study. Int J Occup Environ Health 2009; 15(3): 274-81.

37. Rudyk C, Litteljohn D, Syed S, Dwyer Z, Hayley S. Paraquat and psychological stressor interactions as pertains to Parkinsonian co-morbidity. Neurobiol Stress 2015; 2: 8593.

38. Blair A, Cantor KP, Zahm SH. Non-Hodgkin's lymphoma and agricultural use of the insecticide lindane. Am J Ind Med 1998; 33: 82-7.

39. Quintana PJE, Delfino RJ, Korrick S, et al. Adipose tissue levels of organochlorine pesticides and chlorinated biphenyls and the risk of non-Hodgkin's lymphoma. Environ Health Perspect 2004; 112: 854-61.

40. Brauner EV, Sorensen MA, Gaudreau E, et al. A prospective study of organochlorines in adipose tissue and risk of non-Hodgkin lymphoma. Environ Health Perspect 2012; 120(1): 105-11.

41. Rothman N, Cantor KP, Blair A, et al. A nested case control study of non Hodgkin lymphoma and serum organochlorine residues. Lancet 1997; 350: 240-4.

42. Alavanja M, Bonner M. Occupational pesticide exposure and cancer risk. A Review. J Toxicol Environ Health Critic Review 2012; 1594: 238-63.

43. Alavanja MCR, Ross MK, Bonner MR. Increased cancer burden among pesticide applicators and others due to pesticide exposure. Cancer J Clin 2013; 63(2): 120-42.

44. Abdollahi M, Mostafalou S, Pournourmohammadi, S, Shadnia S. Oxidative stress and cholinesterase inhibition in saliva and plasma of rats following subchronic exposure to malathion. Comp Biochem Physiol 2004; 137: 29-34.

45. Galloway T, Handy R. Immunotoxicity of organophosphorous pesticides. Ecotoxicology 2003; 12: 345-63. 
46. Chiu BC, Dave BJ, Blair A, Gapstur SM, Zahm SH, Weisenburger DD. Agricultural pesticide use and risk of defined subtypes of non-Hodgkin lymphoma. Blood 2006; 108: 1363-9.

47. Schroeder JC, Olshan AF, Baric R, et al. Agricultural risk factors for subtypes of non-Hodgkin's lymphoma. Epidemiology 2001; 12: 701-9.
48. Zahm SH, Weisenburger DD, Saal RC, Vaught JB, Babbitt $\mathrm{PA}$, Blair $\mathrm{A}$. The role of agricultural pesticide use in the development of non-Hodgkin's lymphoma in women. Arch Environ Health 1993; 48(5): 353-8.

49. Jones RR, Yu CL, Nuckols JR, et al. Farm residence and lymphohematopoietic cancers in the lowa Women's Health Study. Environ Res 2014; 133: 353-61. 